\title{
International Cooperation in Prevention and Combating Human Trafficking in Southeast Asian Region: A Case Study of Vietnam
}

\author{
Tran Quang Huyen \\ People's Police College I, Thanh Xuan District, Hanoi 100000, Vietnam
}

\begin{abstract}
In recent years, Vietnam has recorded as transnational hubs among of complicate region relating human trafficking. The distinguish features of geography shared borderland with three countries, namely Cambodia, China and Laos, making cross-border trafficking in persons more dynamic and even more challenged for law enforcement agencies to prevent and combat this crime. Alongside with internal efforts to anticipate human trafficking, from 2010 to 2020, Vietnam's government implemented officially two national programs on prevention and combating human trafficking with a number of specific projects and its related goals. Amongst, to enhance international cooperation between neighbored countries and regional and international partnerships that is considered as one of the most prioritized strategies of Vietnam. This paper focuses on analysis policies and implications of Vietnam through providing details of the current viewpoints in international cooperation to fight trafficking in human beings. Some main trends and patterns of human trafficking in Vietnam in the past years will illustrate the nature of complex situation. Then, some recommendations call for further research to ensure the effectiveness of international cooperation.
\end{abstract}

Keywords: Human trafficking; crime prevention; international cooperation; Vietnam

DOI: $10.7176 / \mathrm{JLPG} / 94-04$

Publication date: February $29^{\text {th }} 2020$

\section{Introduction}

Trafficking in persons is a form of modern slavery. This violation of human rights forms a kind of invasive crime to the individual and the State, which needs to be recognised and punished by legal means (Hoang et al., 2018; Nhien, 2016; Stockl, Kiss, Hoehler, Dung, \& Zimmerman, 2017). Human trafficking, which means the implementation of the purchase-sale of persons, or the recruitment, transportation, transfer, storage, or reception, for exploitation of the person. Being aware of the danger of this type of activity, as well as the need to cooperate at an international level for prevention and trafficking in people, the international community has made joint agreements through international documents to create a legal basis for controlling these criminal acts (Hoang et al., 2018; Ngoc, 2019; Nhien, 2016; Stockl et al., 2017). These international legal documents have been supporting the international community and the nations fighting for trafficking in people who can mention, including the International Convention on the Rights of Children in 1989; the United Nations Convention on combating transnational organised crimes in 2000 (UNTOC); The Protocol to support UNTOC for prevention of the illegal emigration by road, sea, and non-replenishment.

In recent years, the situation of human trafficking crimes, especially trafficking in women and children has become a problem, tends to increase on a global scale and is very complicated (UNODC, 2018). Along with the situation of trafficking in drugs and weapons, human trafficking activities have brought a very high profit to traffickers in the world. According to the estimates of the International Labor Organization (ILO), the profits earned from trafficking offences activities amount to about US \$ 150 billion per year, of which the US \$99 billion comes from commercial sex activities, 34 billion USD comes from human trafficking activities aimed at exploiting labour in construction sites, export processing factories, mines (ILO, Walk Free Foundation, \& IOM, 2017). It is this considerable profit that has made human trafficking lines spread to countries and territories around the world, from Asia, Europe, to countries in Africa, America. In the past, human trafficking is often seen primarily for sexual exploitation; however, human trafficking for labour exploitation is becoming more and more popular and is being paid more attention by countries (Campell \& Davison, 2012; UNODC, 2016, 2018). Most countries around the world consider human trafficking to be a crime against humanity, a form of "modern slavery" that seriously violates fundamental human rights and causes consequences. heavy consequences for society. Therefore, human trafficking crimes are identified by the United Nations as a global problem, requiring member states to make every effort to prevent, prevent and eliminate these crimes.

\section{Human Trafficking in Vietnam: At a Glance}

In Vietnam, the situation of human trafficking activities in recent years has continued to be very complicated, with an increasing trend in both the number of cases and the dangerous nature of crimes (Huong, 2015; Phuong, 2015). According to the Department of Police Crime Investigation, Ministry of Public Security, in the past five years between 2012-2017, the number of trafficked and suspicious victims was 3,090; in which 2,571 people returned, and 519 had not returned (MPS, 2018a). Also, 868 women were absent from the city for a long time, and thousands 
of people who were overseas had no conditions to verify, determining whether they were victims or not (MPS, 2018a). More than $90 \%$ of trafficked victims are women, children and the majority of ethnic minorities, often concentrated in rural areas, especially in remote areas (MPS, 2018a). The agency has prosecuted 1,021 cases, 2,035 accused, accounting for $97.3 \%$ of the reports and indictments received and processed (MPS, 2018a).

Statistics show that in 2018, the whole country detected 192 cases, 256 objects, sold more than 309 victims. In particular, human trafficking to China accounts for more than $80 \%$, to Laos and Cambodia accounted for $10 \%$, the rest is brought to other countries by air and sea, with sophisticated nature and insidious trick (MOLISA, 2018; MPS, 2018b). The typical methods of current human trafficking crimes are through a close relationship with the victim; the subjective victim is caught off guard, likes to explore to approach, get acquainted, entice, entice, invite him or her to go travel, buying gifts, promising to find high-income jobs to cheat selling victims (Hoang, 2017; Hoang et al., 2018; Nhien, 2016). Taking advantage of disguised activities such as organising tourism, studying, labour export brokerage to coordinate the sending of people to foreign countries then illegally and forcibly rescuing the victims (MPS, 2018a). Notably, in the current period, taking advantage of the development of information technology, through mobile phones, social networking sites (Zalo, Facebook), criminals seek to do acquaint, make friends, pretend to love to seduce, cheat, create trust and then deceive victims (Hoang et al., 2018; MPS, 2018a; Stockl et al., 2017).

In recent years, the situation of criminal activities, especially bringing Vietnamese people to Vietnam illegally to exit countries with signs of trafficking with complicated developments. Lines that receive and take people from Vietnam to China with a general passport (or apply for a travel document), for tourism purposes, then use a fake Chinese passport to apply for a visa to enter scenes into Europe; or organise the departure of people from Vietnam to Russia by air and hide in vans to enter Eastern Europe, Belgium, England or France (Hoang, 2017; Hoang et al., 2018; Nhien, 2016). Besides, there is a situation of sending Vietnamese people to Taiwan to work illegally through dividing into small groups by criminals to China by road or air, then taken to international waters by small boats and transferred to fishing vessels to enter the country left allowed to enter Taiwan, with a fee of 4,000 to 6,500 USD/person (MOLISA, 2018; MPS, 2018b). Besides, there are many cases of trading and appropriating tissues and organs which are also very complicated, with many transnational organ trading lines, mainly kidneys; at the same time, many lines of women have been discovered in foreign countries to "give birth" to illicit profits (Ngoc, 2019; Stockl et al., 2017).

The cause of the situation of human trafficking in the past time comes from many different reasons, of which, the real purpose is the negative side of the market mechanism and the process of world economic integration. As a result, social life leads to an increase in the gap between rich and poor, disparities in living conditions between urban and rural areas; pragmatic lifestyle, cult of material values make many people disregard the laws and social ethics to commit crimes for self-seeking purposes (Hoang et al., 2018; Nhien, 2016; Stockl et al., 2017). The impact of human trafficking crimes in the world and the region is directly affecting the situation of human trafficking crimes in Vietnam (Blue Dragon, 2018; MPS, 2018a). Trafficking offenders take advantage of the smooth movement between countries and take advantage of modern information technology to collide and form transnational trafficking lines (Hoang, Thanh, \& Anh, 2015; Tuan \& Thanh, 2013). Also, the demand for sex outside of marriage, the need to find cheap labour in some countries in the region and around the world are the causes for the crime of trafficking in persons and complicated movements, forming lines, gangs, and organisations trafficking in persons (Beadle \& Davison, 2019; Hoang et al., 2018). Because of the need for gaining more money to serve their life, some people have been seduced, deceived, and become victims of crime (Oanh, Toan, \& Hai, 2020). Victims gullible caught off guard or byword should be tricked, dragged and exploited by criminals (Anh, 2014; Huong, 2015).

There are several reasonable causes to lead the situation of human trafficking in Vietnam still complicated and even increase cases and victim (Oanh et al., 2020). One is the effectiveness of legal protection agencies in the fight against trafficking in persons that is not strict (Hoang, 2017; Hoang et al., 2018). Second is the use of measures and means to prevent and fight against this type of crime that is still limited (Nhien, 2016; Phuong, 2015). The third is the coordination in detecting and exchanging information and case files between forces, law enforcement and judicial agencies that are also inconsistent, which has significantly affected the outcome of handling trafficking crimes people before the law (Hoang et al., 2018; Ngoc, 2019; Nhien, 2016). Lastly, many legal provisions related to this field also reveal limitations, shortcomings and incompatibilities with the requirements of international law (Ngoc, 2019; Nhien, 2016). Amongst, the issue of international cooperation between Vietnam and other countries in the prevention and combat of human trafficking has achieved many significant results, especially in cooperation in information exchange and support of investigation, arresting criminals as well as rescuing and accepting returned trafficked victims (Oanh et al., 2020). However, in addition to international aid in the prevention and combat of human trafficking crimes, there are difficulties and obstacles, especially in the cooperation mechanism and incompatibility in the laws of countries. 


\section{International Cooperation: An Essential Tool to Improve the Effectiveness of Combating Human Trafficking in ASEAN}

ASEAN Convention on the Prevention and Control of Trafficking in Persons, Especially Women and Children (ACTIP), was signed by ASEAN leaders on November 21, 2015 at the 27th ASEAN Summit in Kuala Lumpur, Malaysia. The ACTIP is the only regional binding convention on human trafficking outside of Europe. This document also expresses the strong commitment and unprecedented shared commitment of member states in the fight against human trafficking.

In addition to the Preamble, the ACTIP Convention consists of 7 Chapters, 31 Articles, defining the purpose, scope of application, rights and obligations of member states, jurisdiction, and international cooperation in preventing and combating acts. vi human trafficking, dispute resolution procedures through talks and negotiation between member states through diplomatic channels or other peaceful means to reach an agreement. The purpose of the ACTIP Convention is to effectively prevent and combat human trafficking, especially women and children, and to punish human trafficking; protecting and supporting the victims; promote effective cooperation between member states (DFAT, 2019).

Members of the Convention agreed to criminalize trafficking in persons, identify human trafficking offenses, criminal groups related to human trafficking and punish those offenses with appropriate penalties. (Article 5, 6, 7, $8,9)$. Countries may take necessary measures within the framework of their national laws to investigate, prosecute and adjudicate crimes within their jurisdiction; take appropriate measures against offenders or suspects committing crimes according to criminal or extradition proceedings (Article 10). For the protection of victims of trafficking, members may coordinate with non-public organizations to assist victims; ensure the safety of victims when they are in their territory temporarily or permanently; cooperate with relevant social organizations to support and protect trafficked victims (Article 14), and at the same time, facilitate the repatriation of trafficked victims or return to the country where the victims are trafficked. leave (Article 15).

The ASEAN Senior Officials Meeting on Transnational Crime (SOMTC) was tasked with promoting, monitoring, evaluating and periodically reporting to the ASEAN Ministerial Meeting on Transnational Crime on its implementation. effective of this Convention. The ASEAN Secretariat will provide support for supervising and coordinating the implementation of this Convention and support SOMTC in relevant matters.

In addition, the Convention provides for the protection of national sovereignty, territorial integrity, jurisdiction, and the principle of non-interference in each other's internal affairs; without prejudice to obligations arising between Member States under the provisions of other international agreements and when Member States agree, and at the same time do not prevent States from supporting each other in accordance with the provisions of Other international treaties or domestic laws (The ASEAN Secretariat, 2016).

This is a regional multilateral treaty designed to effectively prevent and combat trafficking in persons, especially women and children, and ensure appropriate and effective sanctions against those human trafficking acts; protect and support trafficked victims effectively, with full respect for their human rights; promote effective cooperation between member states to achieve the identified purpose (Hoang, 2017). Each State Party has jurisdiction over crimes occurring in its territory, on ships carrying the flag of that State or on aircraft registered under its laws. Member States also have jurisdiction over cases of offenders who are citizens or stateless persons permanently residing in the territory of that State (DFAT, 2019). In addition, a state may establish jurisdiction if the crime is committed against its citizens; acts of participating in organized and organized criminal groups outside the territory of the member state in order to commit a serious crime within the territory of that member state (Article 10 ACTIP).

Member States shall establish their jurisdiction over crimes governed by this Convention when the alleged offender is present in the territory of that State Party and shall not extradite him. on the grounds that they are citizens of that member state; when the State Party finds that a suspect is present in its territory but does not extradite him. In order to implement the ACTIP Convention, ASEAN countries also agreed to develop and adopt the ASEAN Action Plan on the implementation of the ACTIP Convention (APA). The APA makes specific actionoriented recommendations within the internal laws and policies of ASEAN members, as well as identifies relevant international obligations, to help countries' functional forces deal with them. effective regional challenges, including human trafficking prevention; victim protection; Criminal prosecution; criminalize; and international cooperation. The plan clarifies challenges for ASEAN member countries in the fight against human trafficking, especially women and children; goals that ASEAN member states are aiming for; action plan; and enforcement and evaluation mechanism.

In Vietnam, on December 13, 2016, the President signed Decision No. 2674/2016 / QD-CTN on ratifying the ACTIP Convention, which officially came into force for Vietnam from March 8, 2017. The ratification of the Convention contributes to the positive, proactive role and affirms the commitment of Vietnam and the ASEAN region in efforts to strengthen cooperation in the prevention and combat of human trafficking, especially women. and children; at the same time, contribute to the implementation of the ASEAN Community Vision 2025 and the ASEAN Community Action Plan for the period 2015-2025. Officially becoming a member of the ACTIP 
Convention not only has a positive impact on Vietnam and the ASEAN region but also brings many benefits, contributing to affirming Vietnam's position and prestige in the region and above. world.

As a member of ASEAN, Vietnam is obliged to implement the 2015 ACTIP Convention on the Prevention of Trafficking in Persons, especially Women and Children. One of those obligations is to internalize the spirit of ACTIP into the Criminal Code, ensuring the compatibility of the Vietnam Criminal Code and ACTIP. From 1999 up to now, the Vietnam Criminal Code has made significant changes to human trafficking crimes, meeting the requirements of international treaties to which Vietnam is a party. In 1999, Vietnam's criminal law did not stipulate human trafficking, only trafficking in women (Article 119 of the 1999 Penal Code) and trafficking, fraudulently exchanging or appropriating children (Article 120 of the Penal Code the 1999). This is incompatible with the Palermo Protocol to which Vietnam is a member, besides, this provision omits male trafficking crimes, therefore, In the 2009 revision, the crime of trafficking in women was changed into trafficking. The purpose of previous criminals only focused on trading for prostitution purposes, in 2009 added the purpose of removing victims' organs in Clause 2, Article 119.

In 2015, the crime of trafficking continued to be completed in order to comply with the international treaties to which Vietnam is a member, especially the ACTIP Convention that ASEAN signed in 2015 to meet the requirements of fighting against. Crime trafficking area. Crime of trading, fraudulently exchanging or appropriating children as prescribed in Article 120 of the 1999 Penal Code (amended and supplemented in 2009) has been prescribed into three different crimes in the 2015 Penal Code, which reflects correctly the behavioral nature of these criminals. They are trafficking in persons under 16 years old (Article 151); fraudulently exchanging people under 1 year of age (Article 152) and appropriation of people under 16 years old (Article 153). In addition, the Criminal Code 2015 has clearly defined the elements that constitute the crime in the law, not general provisions like 1999 and 2009.

\section{Regional cooperation and International Cooperation in Prevention and Combating Human Trafficking: A Legal Approach in Vietnam}

To date, Vietnam has participated to sign, ratify and approve a number of international legal regulations in prevention and fighting human trafficking. It includes Convention on the Elimination of All Forms of Discrimination against Women (ratified 17/02/1982), Convention on the Rights of the Child (ratification 28/9/1990), the protocol is not required to complement the Convention on Child Rights in the sale of children, child prostitution and child pornography (ratified 20/12/2001). Particularly, Vietnam has joined the United Nations Convention against Transnational Organized Crime (UN TOC) since $8^{\text {th }}$ June 2012 as well as signed and ratified Protocol on the prevention and suppression of trafficking in particular trafficking in women and children since $29^{\text {th }}$ December 2011 and the International Labour Organization's Convention No. 29 on Anti-Forced Labour. Notably, Vietnam also signed the ASEAN Convention against Trafficking in Persons (ACTIP) together with other members since 2015 at the $27^{\text {th }}$ ASEAN Summit in Kuala Lumpur - Malaysia. In Vietnam, on 13 ${ }^{\text {th }}$ December 2016, the President signed Decision No.2674/2016/QD-CTN approving the ACTIP Convention, and the Convention officially takes effect for Vietnam from 8th March 2017. The ratification of the Convention contributes to demonstrating an active and proactive role, affirming the commitment of Vietnam and the ASEAN region in its efforts to strengthen cooperation in prevention and control of human trafficking, especially women and children. At the same time, we have been engaged in regional initiatives to prevent the victims of trafficking in women and children. The Ministry of Labour-Invalids and Social Affairs was the Government's national focal body involved in two Mekong sub-region projects on the anti-trafficking of women and children, funded by the ILO//PEC and UNDP (code RAS/98/H01). Vietnam joins and signed Memorandum of Action and Action Plan 06 the Mekong Urine (Laos, Cambodia, Thailand, China, Myanmar and Vietnam). Signed bilateral agreements with Cambodia (2005); Vietnam, Thailand (2008), Vietnam-China (2010), coming here will sign Vietnam-Laos. Besides, Vietnam has signed 15 bilateral agreements and 13 legal assistance agreements on the prevention of crime with countries, including content prevention and trafficking crimes.

Due to the transnational identity, human trafficking is not only national concern but also global threats. Viet Nam has actively participated in international cooperation in the field by participating in the implementation of projects such as "Assessment and proposal of policy amendments, strategic plans on child sexual abuse prevention period 2001-2010"; "To improve the prevention and protection of Children's law policy and child sexual abuse" measuring UNICEF funding; The project "Anti-abuse and sexual exploitation bar, teenager" sponsored by The United Nations Economic and Social Commission for Asia and the Pacific (ESCAP). Vietnam has implemented regional projects on the prevention of women's sale, children, including the prevention and sale project of women and children in the sub-Mekong region "sponsored by the International Organizations Alliance, Code RAS/98/H01, regional project, anti-sale of women and children in the sub-Mekong region" sponsored by ILO/IPEC. Both projects focus on media information activities, raising awareness; investigating the cause of the situation; building intervention models; vocational, job creation, community integration for the victims of buying and selling. Aiming as a general goal is to prevent development, reduce the highest level of the sale of women and children. 
Bilateral agreements that Vietnam has concluded with China and Australia are essential legal tools for preventing, detecting, investigating, prosecuting and punishing human trafficking. In the future, we need to continue our research and negotiations to sign similar bilateral agreements regarding judicial assistance with countries in the Mekong region. These agreements should commit to cooperate in the exchange of information, gather evidence, testimony, transfer of documents as well as to conduct tracing, suspension and asset blockade activities. These collaborative activities should also be adopted by a focal authority to operate and accelerate the progress of collaborative activities. Especially in the year 2011, Vietnam has had a program in action prevention, crime prevention and trafficking in the 2011-2015 period and adopted the anti-trafficking law. The anti-trafficking law has spent a chapter of four statutes (from article 53 to 56) on the issue of international cooperation to show the policy of international cooperation in the field of prevention and sale of people on the principle of equality, voluntary, independent respect, sovereignty. Besides, Viet Nam also creates favourable conditions for the repatriation of victims who are foreigners returning to the country in which he or she has a final permanent residence; to apply measures to help the victim return is carried out in accordance with the law and international agreements between Vietnam and the countries, ensuring the safety of life, health, honour, dignity of the victim. The legal assistance of the judiciary is also valued based on international treaties to which Vietnam and the country are jointly members or on the principle of travel under the laws of Vietnam, international law and practices, in particular the priority of the country to sign bilateral treaties with Vietnam. The issue of international cooperation is also regarded as one of the most mainstream contents in this first National Program.

In 31 December 2015, based on remarkable achievements of the National Program 2011-2015 (Decision No.2546/QD-TTg), Vietnam's government still issued the new plan in the period of 2016-2020 with the purpose for reducing human trafficking risks; reduce human trafficking crimes; effectively carry out the tasks of receiving, protecting and supporting victims in returning home. In the whole of the plan, the Government still highlighted the significant role of international cooperation in preventing and combating human trafficking, that is a necessary task. In Decision No.2546/QD-TTg, strengthening international cooperation in implementing the program has been mentioned and being taken as one of the five objectives in the section of specific goals. Regarding the prioritised routes in this National Program, Vietnam still preferred for routes, key locations, major cities and provinces bordering China, Cambodia and Laos. It noted strengthening of international cooperation, mobilising financial support, professional advice, combating crimes of human trafficking, prioritising the signing and implementation of agreements, bilateral and multimodal cooperation agreements with countries, international organisations, especially countries with borders, countries in the region, and countries with a majority of Vietnamese have been sold.

Under leading agency of the Ministry of Public Security with coordinating of multiple agencies such as Ministry of Foreign Affairs, Ministry of Justice, Ministry of Labor, Invalids and Social Affairs, Ministry of Defence, the Supreme People's Procuracy, the Supreme People's Court, Vietnam Women's Union and relevant ministries, sectors, the Project 5 "International cooperation in human trafficking prevention and fighting" between 2016 and 2020 towards essential four targets. They includes target 1: 100\% of human trafficking cases associated with foreigners shall be handled under coordination between the country's functional agencies and law enforcement forces of other countries and relevant organisations; target 2: 100\% of international treaties, international agreements on human trafficking prevention and fighting to which Vietnam is a signatory shall be implemented; target 3: $100 \%$ of international agreements on human trafficking prevention and fighting to which Vietnam is a signatory shall be reviewed periodically and planned for implementation in the next time; and target 4: to end of 2020 , the promotion of activities of studying, surveying and defining mechanism of cooperation, agencies (as head contacts) for cooperation shall be carried out with at least five countries; the signing of international treaties, international agreements on cooperation in human trafficking prevention and fighting shall be executed with at least two countries.

To achieve these above goals, the new National Program between 2016 and 2020 requested all government's agencies to focus on main activities:

+ Implement international agreements and international commitments to human trafficking prevention and fighting to which Vietnam is a signatory, especially the UNTOC, the Protocol to Prevent, Suppress and Punish Trafficking in Persons, especially Women and Children, ASEAN Joint Declaration, COMMIT Joint Declaration, Bilateral Cooperation Agreement between Vietnam and Cambodia, Laos, Thailand, China on human trafficking prevention and fighting.

+ Strengthen cooperation in exchange of information, settlement of human trafficking cases, pursuing and capturing criminals, rescuing victims, sharing experience and training to enhance capacity for human trafficking prevention and fighting;

+ Organise study and investigation of human trafficking activities and learn about policies and laws of the countries where most of the victims are Vietnamese to identify the agencies (as head contacts), mechanism of cooperation in exchange of information, settlement of human trafficking cases, rescuing victims and capturing criminals.

+ Make preliminary and summary wrap-up reports on the implementation of international agreements, 
international treaties or any cooperation agreements signed between Vietnam and other countries for human trafficking prevention and fighting, propose amendments and supplements thereto to competent authorities if necessary.

+ Study and put forward proposals to competent authorities for construction, negotiation, accession and implementation of international agreements, international treaties or other cooperation agreements with other countries, international organisations, non-governmental organisations and individuals as foreigners for human trafficking prevention and fighting in accordance with laws of Vietnam.

+ Organise visits from international delegations or oversea trips for Vietnamese delegations to learn and share experience in the area of human trafficking prevention and fighting; organise international conferences, workshops and forums on human trafficking prevention and fight in Vietnam.

\section{Conclusions with Main Recommendations}

In the coming time, the situation of human trafficking crimes in the world, especially in the Southeast Asian region, is still complicated due to many push-and-pull factors. It includes gender imbalance in some countries, underemployment, migration from rural and mountainous areas to big cities. Additionally, the downside of the market mechanism as well as the introduction of many types of culture, entertainment, pragmatic and unhealthy lifestyles from the outside has affected a significant part of the population, especially increasing the trend of virtual living, urgent life, like to enjoy, get rich quick from young groups. It is likely to become potential and vulnerable victim be easier seduce and recruit by traffickers.

To prevent and combat effectively to human trafficking, in recent years, the Government of Vietnam has been continuing to request all ministries, branches, and localities at all level, from headquartered, provincial to the district, to implement earnestly and apply comprehensively many strategies, programs and methods. Accordingly, these agencies had advised the party committees, authorities to organise and thoroughly plans to implement highly effective implementation of documents issued by the National Assembly, the Government, the Prime Minister concerning prevention and control of human trafficking and illegal migration. However, human trafficking in the Southeast Asian region in general and Vietnam in particular, has been still occurring more complex and unforeseeable. This battle needs more cooperative activities among international, regional and national agencies, particularly to law enforcement agencies of all ten countries in Southeast Asia.

Regarding international cooperation in the prevention and combat of human trafficking crimes in the coming time, Vietnam and other countries and organisations should focus on well solving the following basic issues:

Firstly, it is necessary to continue deepening cooperation with global international organisations, regional organisations and neighbouring countries through the mechanism of signing multilateral and bilateral treaties on prevention against crimes, including treaties on human trafficking.

In the coming time, it is necessary to continue to improve the international cooperation mechanism between Vietnam and other countries in the prevention and combat of human trafficking. In which, joining in multilateral treaties relating combating human trafficking should continue to prioritise as an important role in international cooperation. In addition, Vietnam should enhance to participate in a number of other cooperation channels to serve the fight against human trafficking crimes, including Interpol and Aseanpol cooperation; ASEM cooperation (Asia - Europe cooperation process); cooperation in the Mekong subregion (COMMIT process). Also, there is nontreaty-based cooperation, which is that in many cases, international cooperation does not necessarily rely on treaties; alternatively, cooperation on a reciprocal basis, which is a conventional and long-standing practice principle in international cooperation, is a guarantee of the sending country requesting assistance. Reciprocity is also understood as a familiar customary principle, based on goodwill and social relations, which often happens to neighbour's countries.

Secondly, strengthening cooperation, exchange and working between Vietnamese functional agencies and international organisations and relevant useful agencies to exchange information in prevention and fighting human trafficking.

To effectively prevent and combat human trafficking in the next time, it is necessary to strengthen to exchange information among shared border countries. In fact, the common characteristic of this type of crime is cross-border movement through many countries. Therefore, the authorized agencies, including the Ministry of Public Security (MPS), need to increase their working activities and exchange with international organisations about Vietnam's results and efforts in the prevention and combat of human trafficking as well as cases and cases related to transnational human trafficking. The MPS should continue to maintain the mechanism of briefings and information exchanges with relevant agencies of countries, especially with China, Cambodia, Laos and others. Mainly, annual time, Vietnam should set up a delegation, welcome a delegation in, to exchange, visit, share and learn experiences in the field of human trafficking prevention. Localities, especially provinces bordering China, Laos and Cambodia, have strengthened cooperation with the same-level authorities of countries to exchange information, maintain hotlines, periodic briefings and electricity negotiating, dispatching, exchanging information related to the situation of human trafficking crimes and verifying cases of Vietnamese victims and citizens illegally residing overseas. 
In addition, the Ministry of Foreign Affairs also needs to strengthen the work of directing missions abroad, especially those with a large number of Vietnamese people being trafficked to ensure the situation of human trafficking crimes are related to the public. Promote the propaganda and improve the operational efficiency of the Centre for the protection of Vietnamese citizens in foreign countries to promptly support Vietnamese citizens abroad and victims of trafficking. To create a comprehensive legal basis for cooperation in the fight against human trafficking, apart from bilateral agreements, the concerned ministries and branches should continue to strengthen the establishment of a network of liaison officers to confer exchange information on the situation of human trafficking crimes or cooperation projects with international organisations and non-governmental organisations on human trafficking prevention.

Thirdly, strengthening the coordination between the functional forces in the investigate human trafficking cases when it occurred at Vietnam and/or their partnership's areas to discover and rescue victims and arrest criminals. Through promoting international cooperation, human trafficking prevention and control activities of the Ministry of Public Security and Border Guards should coordinate closely with each other as well as cooperate with functional forces of the Ministry of Public Security. Cambodia, Laos and China to regularly conduct border checks and critical areas where illegal exit activities take place to prevent trafficking in persons. At the same time, the Ministry of Public Security and its related units should continue to cooperate with the functional forces of neighbouring countries such as the Border Guard, the Chinese Police, Cambodia and Laos to suppress trafficking crimes on border routes, organise basic investigations, firmly grasp the situation of human trafficking activities, promptly handle information, organise investigations and trace arresting people in trafficking lines; rescuing and supporting victims of trafficking.

Fourthly, enhancing training and retraining of officials to ensure the political, legal, professional and foreign language skills to meet the requirements in international cooperation on crime prevention.

To ensure that the prevention, detection and combat of trafficking in persons are accurate and in accordance with the law, it is necessary to organise training and fostering of legal knowledge for investigators, prosecutors and judges. in the fields of criminal extradition, international criminal justice assistance transferring international prisoners. Particular attention is paid to the specialised staff (Interpol). Need to increase the number to have a strong team, to meet the requirements of the times. The State should create conditions for law enforcement agencies to strengthen foreign relations, survey and learn from other countries' experiences to apply them to specific circumstances of Vietnam, improve room efficiency, combating the crime of human trafficking.

Fifthly, the Government should integrate the competences and responsibilities between the Ministry of Public Security, the Ministry of Justice, the Ministry of Foreign Affairs, the Supreme People's Court and the Supreme People's Procuracy in carrying out foreign affairs and international cooperation in terms of preventing human trafficking. At the same time, review and amend the provisions of Vietnamese law under the provisions of international law will create a favourable legal corridor for international cooperation in the prevention and combat of human trafficking.

\section{Reference}

Anh, K. D. (2014). Engendering the evaluation of anti-trafficking policy: The Vietnamese National Action Programme against trafficking in women and children 2004-2010. (PhD in Women's and Gender Studies). The University of Waikato, Halmiton, New Zealand.

Beadle, D., \& Davison, L. (2019). Precarious Journeys: Mapping Vulnerabilities of Victims of Trafficking from Vietnam to Europe. Retrieved from London: https:/www.antislavery.org/wpcontent/uploads/2019/03/Precarious-Journeys-Mapping-vulnerabilities-of-victims-of-trafficking-fromVietnam-to-Europe.pdf

Blue Dragon. (2018). Human Trafficking in Vietnam. Retrieved from Hanoi, Vietnam: https://www.bluedragon.org/wp-content/uploads/2019/04/Human-Trafficking-in-Vietnam-fact-sheet.pdf

Campell, D., \& Davison, N. (2012). Illegal Kidney Trade Booms as New Organ Is 'Sold Every Hour'. World. 28 May. Retrieved from https://www.theguardian.com/world/2012/may/27/kidney-trade-illegal-operations-who

DFAT. (2019). ASEAN-Australia Counter Trafficking - Investment Design. Canberra, Australia: Australian Aid

Hoang, T. L. (2017). Human Trafficking in Vietnam: Preventing Crime and Protecting Victims through Interagency Cooperation. (PhD thesis). Queensland University of Technology, Queensland, Australia.

Hoang, T. L., Carrington, K., Hung, T. T., Phuc, T. N., Kien, T. L., \& Ha, N. B. (2018). Inter-Agency Cooperation to Raise Awareness on Human Trafficking in Vietnam: Good Practices and Challenges. Asian Journal of Criminology, 13(3), 251-274.

Hoang, T. L., Thanh, V. T., \& Anh, N. C. (2015). Self-Help Groups for Human Trafficking Victims in Vietnam: An Innovative Program Model. Paper presented at the Crime, Justice and Social Democracy International Conference, Brisbane, Queensland.

Huong, T. L. (2015). Trafficking in Persons in Vietnam: the Root Causes and State Responses to Human Security. In J. Song \& A. Cook (Eds.), Irregular Migration and Human Security in East Asia (pp. 117-135). New York: 
Routledge.

ILO, Walk Free Foundation, \& IOM. (2017). Global Estimates of Modern Slavery. Retrieved from Geneva, Switzerland:

MOLISA. (2018). Training on Prevention of Trafficking in Persons [Press release]. Retrieved from http://www.molisa.gov.vn/vi/Pages/chitiettin.aspx?IDNews=28529

MPS. (2018a). Annual Report for Trafficking in Persons. Retrieved from Hanoi, Vietnam [Vietnamese language]:

MPS. (2018b). Professional Forum on Child Trafficking Prevention [Press release]. Retrieved from http://bocongan.gov.vn/tin-tuc-su-kien/hoi-thao-chuyen-de-ve-nang-cao-hieu-qua-cong-tac-phong-chongmua-ban-tre-em-d17-t24225.html

Ngoc, T. N. (2019). Human Trafficking Crime Awareness Among Remote Communities in Central Vietnam. (PhD $\mathrm{PhD})$. Walden University, Minneapolis, Minnesota.

Nhien, C. P. (2016). Preventing and Combating Women Trafficking from Vietnam to China. (PhD Thesis). University of Northumbria, Newcastle, U.K.

Oanh, V. N., Toan, Q. L., \& Hai, T. L. (2020). Police Failure in Identifying Victims of Human Trafficking for Sexual Exploitation: An Empirical Study in Vietnam. Journal of Crime and Justice. doi:10.1080/0735648X.2020.1724816

Phuong, T. T. H. (2015). Protection for Trafficked Persons in Viet Nam: Another National Security Discourse. International Migration, 53(4), 25-36.

Stockl, H., Kiss, L., Hoehler, J., Dung, T. D., \& Zimmerman, C. (2017). Trafficking of Vietnamese Women and Girls for Marriage in China. Global Health Research and Policy, 2(28), 1-9.

The ASEAN Secretariat. (2016). ASEAN Regional Plan of Action on the Elimination of Violence against Children. Jarkata, Indonesia: ASEAN.

Tuan, A. D., \& Thanh, T. D. (2013). Human Trafficking in Vietnam: Difficulties and Solutions. In C. Taylor, D. Torpy, \& D. Das (Eds.), Policing Global Movement: Tourism, Migration, Human Trafficking and Terrorism (pp. 165-186). New York: CRC Press.

UNODC. (2016). Assessment Toolkit: Trafficking in Persons for the Purpose of Organ Removal. Retrieved from New York: https://www.unodc.org/documents/humantrafficking/2015/UNODC_Assessment_Toolkit_TIP_for_the_Purpose_of_Organ_Removal.pdf

UNODC. (2018). Global Report on Trafficking in Persons 2018. Retrieved from New York: https://www.unodc.org/documents/data-and-analysis/glotip/2018/GLOTiP_2018_BOOK_web_small.pdf 